\title{
Malnutrition assessed by mini nutritional assessment tool among Indian elderly: a systematic review and meta-analysis
}

\author{
Samiran Bisai ${ }^{1,2 *}$, Uposoma Dey ${ }^{2}$
}

\begin{abstract}
${ }^{1}$ Department of Anthropology and Tribal Studies, Sidho-Kanho-Birsha University, Purulia, West Bengal, India ${ }^{2}$ Department of BCW and TD, Cultural Research Institute, Govt. of West Bengal, Kolkata, West Bengal, India
\end{abstract}

Received: 09 August 2020

Revised: 06 October 2020

Accepted: 09 October 2020

\section{*Correspondence:}

Dr. Samiran Bisai,

E-mail: sbisai@hotmail.com

Copyright: () the author(s), publisher and licensee Medip Academy. This is an open-access article distributed under the terms of the Creative Commons Attribution Non-Commercial License, which permits unrestricted non-commercial use, distribution, and reproduction in any medium, provided the original work is properly cited.

\begin{abstract}
Overall health and nutritional status of elderly population of India is not satisfactory. Therefore, present systematic review was conducted to determine the overall occurrence of malnutrition of Indian elderly and furthermore attempted to find out the underlying causes of malnutrition. Present review considered published article reported malnutrition of elderly as assessed by mini nutritional assessment (MNA) tool. Thus, literature searching, screening and data synthesis was made and recorded following preferred reporting items for systematic reviews and meta-analyses (PRISMA) protocol. All published literature looked through utilizing the accompanying keywords. The MedCalc software was applied to estimate the overall prevalence of malnutrition by using meta-analysis statistical method. Thirty of 147 articles were included in this analysis. Overall mean MNA scores was $19.47 \pm 4.17$. Study found overall prevalence of malnutrition among elderly was $17.93 \%$ (95\% CI: $14.23-21.84)$. The prevalence of malnutrition was significantly higher in rural elderly $(21.67 \%$, 95\% CI: $16.44-27.40)$ than urban $(14.23 \%, 95 \%$ CI: $10.02-19.05)$ elderly of India. Rural elderly more likely to be 1.8 (OR: 1.76; CI: 1.56-1.99) times greater chance to be developed malnutrition than the urban elderly. Moreover, present study estimated that about 18.6 million Indian elderly population was malnourished and expected to be 22 million by 2021 due to elderly population growth, morbidity, poverty and joblessness by COVID-19 pandemic. Given the expansion of elderly malnutrition in future, there is felt need a special nutrition intervention programme for the rural elderly population. Thus, a dedicated geriatric friendly nutrition rehabilitation center (GFNRC) may be setup at every community development block of India.
\end{abstract}

Keywords: Elderly, Malnutrition, Meta-analysis, MNA, India

\section{INTRODUCTION}

Populace maturity is a triumph of humankind. It is additionally a greatest challenge within the $21^{\text {st }}$ century, which is put able to increased monetary and social demands on all nations. Reality remains that more seasoned individuals give a precious, often-ignored resource that makes a pivotal commitment to the socioeconomic texture in our lives. ${ }^{1}$ More established individuals are mediators between the past, this, and hence what's to come. Their wisdom and knowledge form lifeline within the society.
In 1950 , only three countries had 20 million population aged 60 and more was China (41 million), India (20 milloin) and the America (20 million), during 2009, the number of nations quite above 20 million individuals matured more than or equal to 60 years including 160 million in China, 89 million in India, 56 million in the United States, 38 million in Japan and 25 million in Russia and 21 million in Germany. ${ }^{2}$

In consonance with Malthus theory of population, India's aged populations will be increased exponentially over the accompanying four decades. Presently, the proportion of 
old populace $(60+)$ records to about $8.6 \%$, framing 104 million with 53 million females and 51 million males. ${ }^{3}$ It is estimated to extend to 133.3 million in $2021,178.6$ million in 2031, 236 million in 2041 and 301 million 2051.,5 The present demographic trends suggest the adulthood reliance would be expanding within the coming years as lifespan expectancy hope has been improving and there would be lesser people within the hands to be the potential sources of help in development. This can be widely applicable among the tribal population likewise in spite of the fact that they structure sizeable proportion of India's population. A noteworthy weight falls on the government likewise to make inventive arrangements. These strategies must address the prerequisites of older people.

Ageing must be a multi-factorial procedure that is controlled by hereditary and environmental factors. ${ }^{6}$ Factors related with maturing changes will be ordered as intrinsic and extrinsic. The intrinsic factors are related with ordinary maturing like hereditary while extrinsic factors incorporate the environment, diet and way of life. It influences physiological capacities and might be characterized on the grounds that the aggregation of injury in molecules, cells and tissues over a lifetime; this regularly diminishes an organism's ability to deal with homeostasis in stress conditions, and involves a more serious hazard for a few diseases (for example malignancy, cardiovascular and neurodegenerative issues) and untimely mortality. ${ }^{7}$

India is witnessing a demographic transition, bringing about a quick increment inside the quantity of older populace. The wellbeing status of the old stays to be an imperative issue in regard of surveying the overall wellbeing status of a populace. Older adults' grown-ups are a conceivably weak gathering for ailing health and malnutrition. Consequently, early identification of malnutrition ought to be a key component of the geriatric health assessment. The mini nutritional assessment (MNA) was proposed by Nestle nutrition institute, 1994; revision 2006 (N67200 12/99 10M), was developed as a dependable screening test to detect malnutrition among elderly. ${ }^{8}$

As of now, there is an indication of the uncommonness of research among the tribal old individuals of India on their nutritional status by utilizing MNA survey which was a horrendously solid instrument for evaluating elderly nutritional status. Besides this, there was no systematic review take a shot at the dietary status of Indian old. Accordingly, present review was led to get a handle on the nutritional status of the older populace.

In view of the above, followings objectives were set out to this review: to summarize the prevailing literatures among the elderly in India so as to inform foundation of latest research; to look out the general nutritional status of elderly population of India; to search out the overall prevalence of malnutrition among urban and rural elderly and to look the key socio-cultural causes which influence the nutritional status among them.

\section{METHODS}

Meta-analysis is a part of systematic reviews; a path for efficiently joining qualitative and quantitative data from a few studies to create one conclusion that has more prominent statistical power. This conclusion is statistically more grounded than the analysis of a study; expanded quantities of subjects, there will be more noteworthy assorted variety among subjects, or collected impacts and results.

\section{Study design}

Present review is sectional nature, systematically gathering information on nutritional status as assessed by MNA of elderly ( $\geq 60$ years of both sexes) in India using the subsequent key words: MNA, nutritional status, elderly, and India; data searching: relevant studies was searched in various search engine as PubMed/Medline, Google scholar, medIND, academia, research gate, EMBASE, science direct scirus, cross references and emails, website, conference programs, dissertations, review articles, and government reports.

\section{Systematic review tool}

Preferred reporting items for systematic reviews and metaanalyses (PRISMA) checklist was used to screened studies (Figure 1).

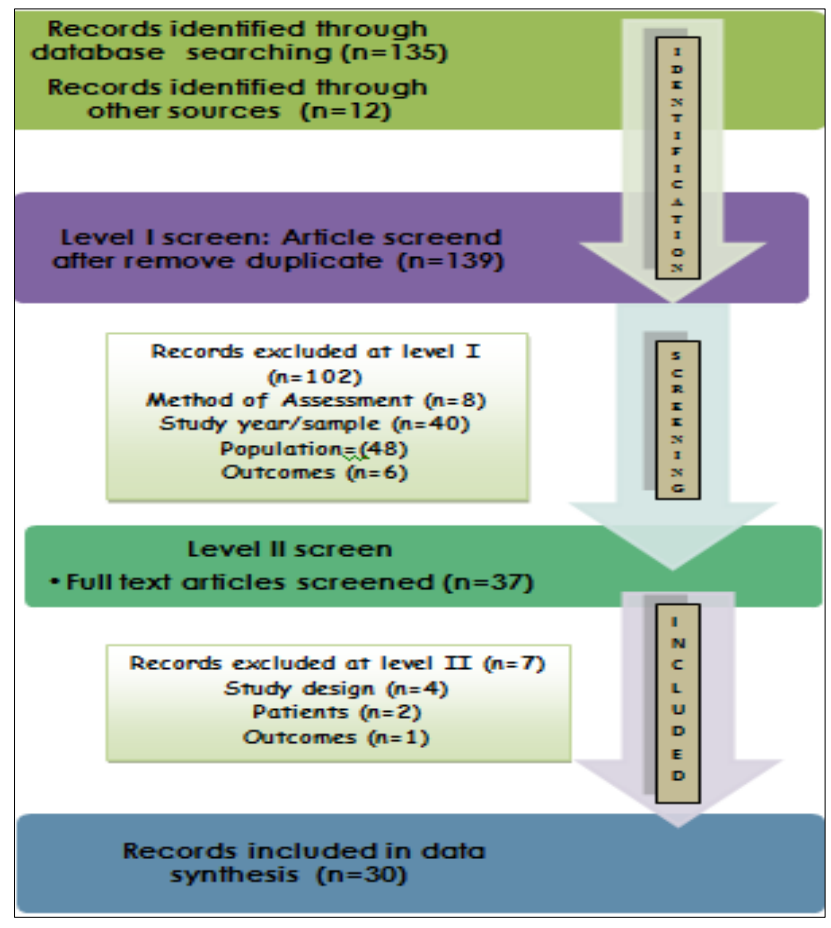

Figure 1: PRISMA flow chart of study selection for meta-analysis. 


\section{Time frame}

Duration of the study was from January 2010 to July 2020.

\section{Study selection}

A total of 30 studies were screened and selected for metaanalysis (Table 1).

\section{Heterogeneity test}

Forest plot was used to calculate the overall prevalence of malnutrition by fixed and random effect method. The funnel plot bolster with $\mathrm{I}^{2}$ statistic scores were used to measured heterogeneity, somewhere in the range of $0 \%$ and $100 \%$. Low, moderate and high heterogeneity was considered as $>25 \%,>50 \%$ and $>75 \%$, respectively. Chisquare and odds ratio was calculated using standard statistical method. All statistical analyses were performed by MedCalc statistical software version 19.2.

\section{RESULTS}

Selected studies on the nutritional status of the elderly in India are shown in Table 1. Altogether 30 out of 147 studies were finally selected for meta-analysis. Altogether 16 sub-studies were selected for rural communities, 17 sub-studies for urban communities. Four institutional based studies were also included within the present review. Mostly nutritional status of individual aged 60 years above was considered to assess elderly nutritional status of India. Methods used in these studies were only MNA questionnaire as proposed by Nestle. ${ }^{8}$ Total sample size was 7374 included during this meta-analyses. Sample size varies from 105 to $545 .^{30,34}$ From the above table we also calculated the mean score of MNA as found from 10 studies to this point. The overall mean MNA score for Indian elderly was $19.47 \pm 4.17$.

Table 2 reveals the possible causes of nutritional status of elderly as found by the previous studies of assessing malnutrition by MNA. Inadequate diet intake, poor economic status and education of the elderly mainly modifiable risk factor associated with malnutrition of the elderly reported by $40 \%, 36.7 \%$ and $30 \%$ studies, respectively. Aging also reported by $40 \%$ studies; gender and marital status reported by $26.7 \%$ and $20 \%$ studies, respectively. Chronic morbidities and psychological health assessed by general health score - 28 were the other causes reported by $26.7 \%$ studies.

Table 1: Selected studies of nutritional status by MNA of elderly in India.

\begin{tabular}{|c|c|c|c|c|c|c|}
\hline $\begin{array}{l}\text { SI } \\
\text { no. }\end{array}$ & Place of study & $\begin{array}{l}\text { Population/re } \\
\text { sidence }\end{array}$ & $\begin{array}{l}\text { Sample } \\
\text { size }\end{array}$ & $\begin{array}{l}\text { Malnutriti } \\
\text {-on }(\%)\end{array}$ & $\begin{array}{l}\text { Associated } \\
\text { factors }\end{array}$ & $\begin{array}{l}\text { Refer } \\
\text {-ence }\end{array}$ \\
\hline 1 & $\begin{array}{l}\text { Pathanamthitta, } \\
\text { Kerala }\end{array}$ & $\begin{array}{l}\text { Urban and } \\
\text { rural }\end{array}$ & 129 & 11.6 & $\begin{array}{l}\text { Education, marital status, family } \\
\text { income, BMI }\end{array}$ & 9 \\
\hline 2 & Kamrup, Assam & Rural & 360 & 15.0 & Age, Gender, diet, economy & 10 \\
\hline 3 & $\begin{array}{l}\text { Nagpur, } \\
\text { Maharashtra }\end{array}$ & $\begin{array}{l}\text { Urban, dental } \\
\text { patient }\end{array}$ & 200 & 19.5 & $\begin{array}{l}\text { Oral health associated with } \\
\text { malnutrition }\end{array}$ & 11 \\
\hline 4 & West Bengal & Urban slum & 132 & 31.8 & Gender, literacy, economy, diet & 12 \\
\hline 5 & $\begin{array}{l}\text { Udaipur, } \\
\text { Rajasthan }\end{array}$ & Rural & 152 & 13.8 & Gender & 13 \\
\hline 6 & West Bengal & $\begin{array}{l}\text { Rural OPD } \\
\text { patient }\end{array}$ & 144 & 31.2 & Gender, economy, chronic diseases & 14 \\
\hline 7 & Kochi, Kerala & $\begin{array}{l}\text { Urban, } \\
\text { community } \\
\text { and institution }\end{array}$ & 296 & 7.0 & $\begin{array}{l}\text { MNA tool may be used as routine } \\
\text { geriatric assessments }\end{array}$ & 15 \\
\hline 8 & $\begin{array}{l}\text { Imphal East, } \\
\text { Manipur }\end{array}$ & Rural & 250 & 20.8 & $\begin{array}{l}\text { Age, sex, marital, education, and } \\
\text { economic status }\end{array}$ & 16 \\
\hline 9 & $\begin{array}{l}\text { Bangalore, } \\
\text { Karnataka }\end{array}$ & Rural & 91 & 30.8 & $\begin{array}{l}\text { Age, } \\
\text { hearing problem }\end{array}$ & 17 \\
\hline 10 & Karnataka & Rural & 190 & 10.1 & Gender & 18 \\
\hline 11 & $\begin{array}{l}\text { Jamnagar, } \\
\text { Gujarat }\end{array}$ & Urban & 400 & 6.75 & $\begin{array}{l}\text { Age, chronic morbidity, economic } \\
\text { dependency status }\end{array}$ & 19 \\
\hline 12 & $\begin{array}{l}\text { Khammam, } \\
\text { Telangana }\end{array}$ & Rural & 209 & 9.1 & $\begin{array}{l}\text { Older age, low education, staying } \\
\text { single, unemployed, low income and } \\
\text { inadequate diet }\end{array}$ & 20 \\
\hline 13 & Ponduchery & Rural & 279 & 17.9 & Inadequate fruits and vegetables intake & 21 \\
\hline 14 & $\begin{array}{l}\text { Dehradun, } \\
\text { Uttarakhand }\end{array}$ & Rural & 192 & 20.8 & Age, gender & 22 \\
\hline 15 & $\begin{array}{l}\text { Mysore, } \\
\text { Karnataka }\end{array}$ & $\begin{array}{l}\text { Urban, } \\
\text { Institution }\end{array}$ & 141 & 15.6 & $\begin{array}{l}\text { Oral health is associated with } \\
\text { malnutrition }\end{array}$ & 23 \\
\hline
\end{tabular}




\begin{tabular}{|c|c|c|c|c|c|c|}
\hline $\begin{array}{l}\text { SI } \\
\text { no. }\end{array}$ & Place of study & $\begin{array}{l}\text { Population/re } \\
\text { sidence }\end{array}$ & $\begin{array}{l}\text { Sample } \\
\text { size }\end{array}$ & $\begin{array}{l}\text { Malnutriti } \\
- \text { on }(\%)\end{array}$ & $\begin{array}{l}\text { Associated } \\
\text { factors }\end{array}$ & $\begin{array}{l}\text { Refer } \\
\text {-ence }\end{array}$ \\
\hline 16 & $\begin{array}{l}\text { Hyderabad, } \\
\text { Telangana }\end{array}$ & Urban & 200 & 14.5 & $\begin{array}{l}\text { Age, education, marital status, dietary } \\
\text { pattern }\end{array}$ & 24 \\
\hline 17 & $\begin{array}{l}\text { North } 24 \\
\text { Paraganas, West } \\
\text { Bengal }\end{array}$ & Rural & 235 & 29.4 & Age, income, literacy, less food intake & 25 \\
\hline 18 & $\begin{array}{l}\text { Kolkata, } \\
\text { West Bengal }\end{array}$ & Urban & 500 & 14.8 & Education and financial support & 26 \\
\hline 19 & $\begin{array}{l}\text { Coimbatore, } \\
\text { Tamil Nadu }\end{array}$ & Urban & 190 & 19.5 & Marital and socio economic status & 27 \\
\hline 20 & $\begin{array}{l}\text { Mangalore, } \\
\text { Karnataka }\end{array}$ & $\begin{array}{l}\text { Urban, } \\
\text { community } \\
\text { and old age } \\
\text { home }\end{array}$ & 210 & 10.9 & $\begin{array}{l}\text { High risk of malnutrition in } \\
\text { old age home than community }\end{array}$ & 28 \\
\hline 21 & $\begin{array}{l}\text { Satara, } \\
\text { Maharashtra }\end{array}$ & $\begin{array}{l}\text { Urban, dental } \\
\text { patient }\end{array}$ & 200 & 36.5 & Oral health & 29 \\
\hline 22 & Karnataka & Rural & 545 & 23.5 & Gender & 30 \\
\hline 23 & Bengaluru & Urban & 300 & 21.3 & $\begin{array}{l}\text { Marital, education, economic status } \\
\text { and living arrangement }\end{array}$ & 31 \\
\hline 24 & $\begin{array}{l}\text { Bangalore, } \\
\text { Karnataka }\end{array}$ & Rural & 181 & 60.2 & Age, chronic morbidities & 32 \\
\hline 25 & $\begin{array}{l}\text { Kolkata, West } \\
\text { Bengal }\end{array}$ & $\begin{array}{l}\text { Urban, old age } \\
\text { home }\end{array}$ & 200 & 22.0 & Psychological stress and depression & 33 \\
\hline 26 & $\begin{array}{l}\text { Devangere, } \\
\text { Karnataka }\end{array}$ & $\begin{array}{l}\text { Urban, old age } \\
\text { home }\end{array}$ & 105 & 24.0 & Age & 34 \\
\hline 27 & $\begin{array}{l}\text { Bikaner, } \\
\text { Rajasthan }\end{array}$ & $\begin{array}{l}\text { Urban and } \\
\text { rural }\end{array}$ & 500 & 11.6 & Age, education and BMI & 35 \\
\hline 28 & $\begin{array}{l}\text { Kolkata, } \\
\text { West Bengal }\end{array}$ & Urban & 226 & 2.1 & BMI, GHQ score, dental health & 36 \\
\hline 29 & $\begin{array}{l}\text { Vellore, Tamil } \\
\text { Nadu }\end{array}$ & Rural & 227 & 14.0 & Protein less diet, less food intake & 37 \\
\hline 30 & Uttar Pradesh & $\begin{array}{l}\text { Urban and } \\
\text { rural }\end{array}$ & 390 & 24.9 & Age & 38 \\
\hline
\end{tabular}

Table 2: Possible causes of malnutrition found by previous studies on elderly in India.

\begin{tabular}{|ll|}
\hline Causes & Percentage of studies \\
\hline Inadequate food intake & 40.0 \\
\hline Ageing & 40.0 \\
\hline Poor economic status & 36.7 \\
\hline Education & 30.0 \\
\hline Gender & 26.7 \\
\hline $\begin{array}{l}\text { Chronic morbidities and } \\
\text { psychological disorder }\end{array}$ & 26.7 \\
\hline Marital status & 20.0 \\
\hline Living arrangement & 6.7 \\
\hline
\end{tabular}

Funnel plot is displayed the studies included in Metaanalysis in a plot of effect size against sample size (Figure 2). In our study, the left corner was not at all that empty, so we ruled out the publication bias. The prevalence of malnutrition in random and fixed effect model of metaanalysis among the elderly in India tabulated in Table 3. The heterogeneity of the study is larger than $75 \%$ (I2) so we took random effect model. The overall prevalence of malnutrition among the Indian elderly was found to be $17.93 \%$ (95\% CI: 14.23 to 21.84 ).

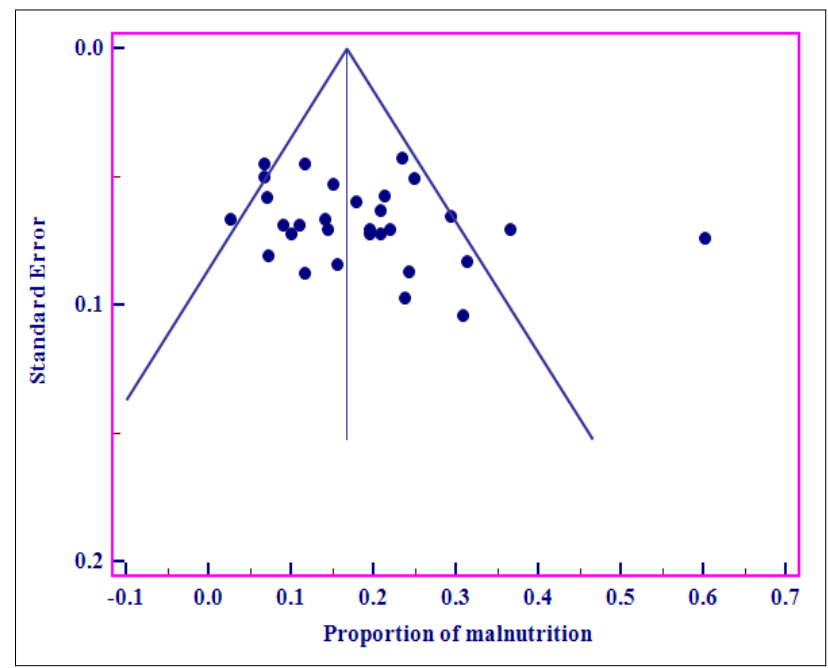

Figure 2: Funnel plot showing proportion of malnutrition. 
Table 3: Proportion of malnutrition and level of heterogeneity among the elderly population of India.

\begin{tabular}{|lllll|}
\hline $\begin{array}{l}\text { Area of } \\
\text { study }\end{array}$ & $\begin{array}{l}\text { Fixed } \\
\text { effect } \\
\text { model }\end{array}$ & $\begin{array}{l}\text { Random } \\
\text { effect } \\
\text { model }\end{array}$ & $\begin{array}{l}\mathrm{I}^{2} \\
(\mathbf{9 5} \%)\end{array}$ & CI \\
\hline $\begin{array}{l}\text { India } \\
\text { (N=7374) }\end{array}$ & 16.73 & 17.93 & $94.52 \%$ & $\begin{array}{l}(93.12- \\
95.64)\end{array}$ \\
\hline $\begin{array}{l}\text { Rural } \\
\text { (N=3500) }\end{array}$ & 21.24 & 21.67 & $93.69 \%$ & $\begin{array}{l}(91.23- \\
95.47)\end{array}$ \\
\hline $\begin{array}{l}\text { Urban } \\
\text { (N=3874) }\end{array}$ & 12.69 & 14.23 & $93.95 \%$ & $\begin{array}{l}(91.71- \\
95.59)\end{array}$ \\
\hline
\end{tabular}

Figure 3 shows the forest plot of meta-analysis of proportion of malnourished among the elderly of India. Each horizontal line represents every study with the result plotted as a box and the $95 \%$ confidence interval of the result displayed in the line. The diamond at the bottom of the forest plot shows the result when all the individual studies are combined together and averaged. The horizontal points of the diamond are the limits of the $95 \%$ confidence interval and are subject to the same interpretation as any of the other individual studies on the plot. Overall 30 studies selected for meta-analysis. The graph indicates that prevalence of malnourishment was highest (60.22\% with 95\% CI: 52.69-67.41) among the elderly of rural Karnataka whereas, lower rate malnutrition (2.1 with 95\% CI: 0.98-5.69) was reported among the rural elderly of Tamil Nadu. ${ }^{32,36}$

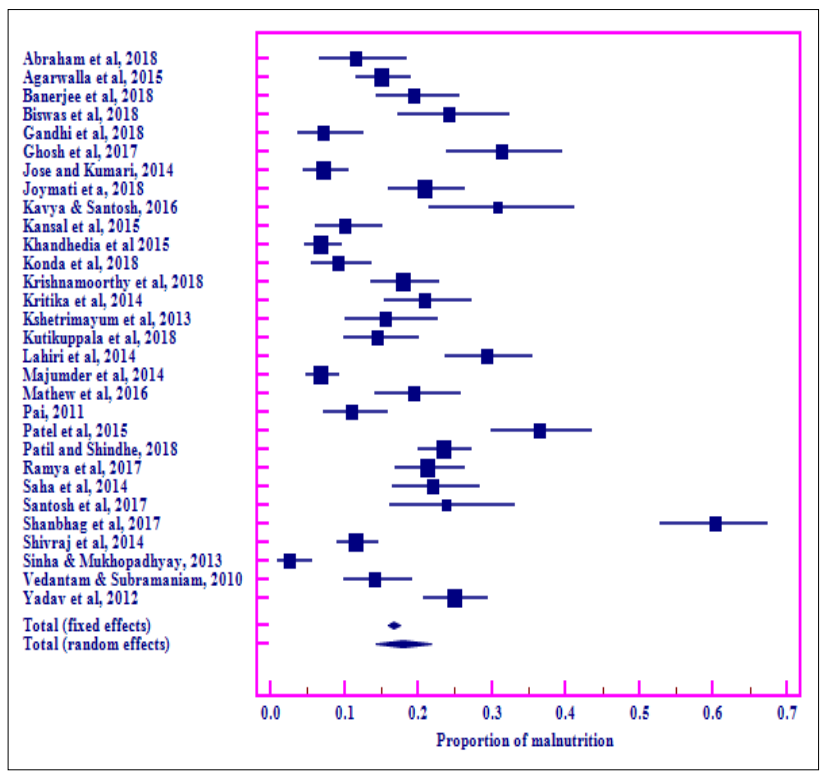

Figure 3: Forest plot of malnutrition by MNA among the elderly in India.

The forest plot of meta-analysis of proportion of malnourished among the rural elderly in India presented in Figure 4. There are 16 studies selected for meta-analysis. The graph indicates that prevalence of malnourishment was highest $(60.22 \%$ with $95 \%$ CI: 52.69-67.41) among the elderly of rural Karnataka as reported by Shanbhag and colleagues whereas, the prevalence rate was found to be $7.24 \%$ (3.67 to 12.58 ) among the rural elderly in the state of Rajasthan. ${ }^{13,32}$ Total rural sample was 3500 with ranging from 80 to $545 .^{9,30}$ The overall prevalence of malnutrition among the rural elderly was found by meta-analysis was $21.67 \%$ (95\% CI: 16.44-27.40).

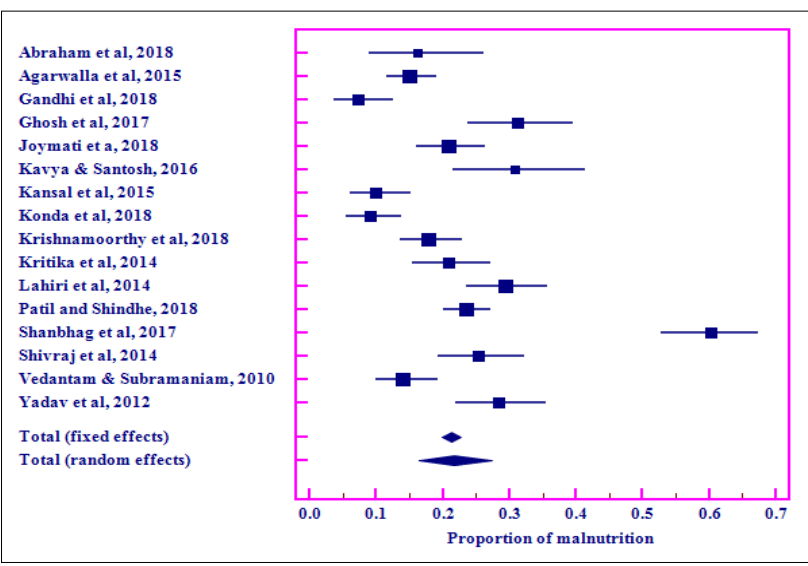

Figure 4: Forest plot of malnutrition by MNA among the rural elderly in India.

The forest plot of meta-analysis of proportion of malnourished among the urban elderly in India is displayed in Figure 5. There are 17 urban studies selected for metaanalysis. The graph indicates that prevalence of malnourishment was highest $(36.50 \%, 95 \%$ CI: $29.82-$ 43.58) among the elderly of urban area of Maharashtra as, whereas, lowest prevalence rate was found to be $2.1 \%$ (95\% CI: 0.98 to 5.69) among the urban elderly of West Bengal as reported by earlier study. ${ }^{21,36}$ Overall urban sample size was 3874 with ranging from 49 to $500 .^{9,26}$ Moreover, the overall prevalence of malnutrition among the urban elderly was $14.23 \%$ (95\% CI: 10.02-19.05). It was observed that the rural elderly people were significantly 1.8 times more chance to be developed malnutrition than the urban elderly (OR: 1.76 ; $\mathrm{CI}$ : 1.56 to 1.99).

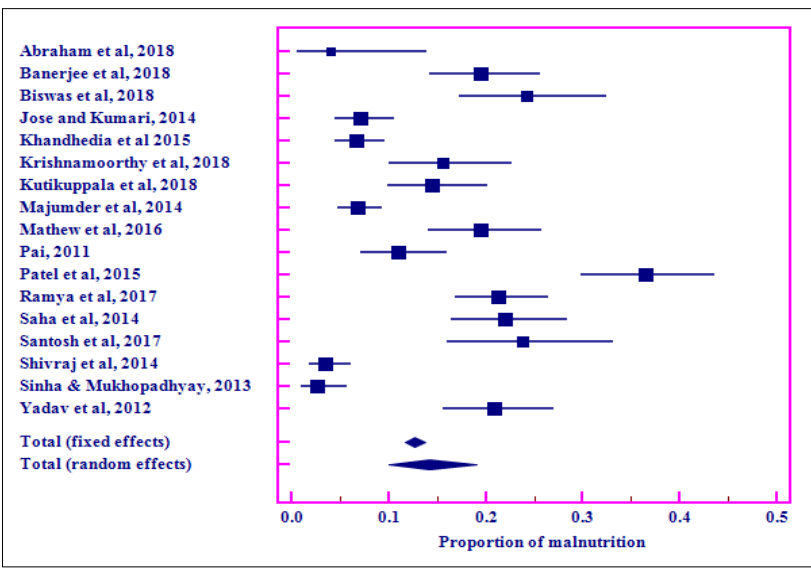

Figure 5: Forest plot of malnutrition by MNA among the urban elderly in India. 


\section{DISCUSSION}

The extent of malnutrition among the elderly in India is underreported. Studies have demonstrated that about $50 \%$ of the older population is malnourished globally. ${ }^{39}$ Most nutritional intervention studies and programs are focused on pregnant and lactating mothers, infants, young children, and teenagers. In India, the nutrition and health status of the elderly is usually neglected more so in rural India. The health of the elderly is aggravated by poor nutrition alongside various co-morbidities which make a twisted cycle that causes increased economic burden on their family and health sector of the nation. Early identification of malnutrition could be an initial move. So, MNA execute many criteria for both screening and diagnostic measures for elderly malnutrition.

The present review summarized the prevalence of malnutrition among the elderly in India for a period of 10year (2010-2020). In this review, pooled prevalence of malnutrition (as per MNA score) was found to be $17.9 \%$. The $\mathrm{I}^{2}$ value indicates that there had large variation of malnutrition in the data set ranging from $2.1 \%$ to $60.2 \%{ }^{30,36}$ Low rate of malnutrition was reported by Sinha and Mukhopadhyay, Shivraj et al, Gnanaselvam et al, and Konda et al. ${ }^{20,30,35,36,40}$ In contrast, very high prevalence of elderly malnutrition was reported by Shanbhag, Patel et al, Ghosh et al and Lahiri et al. ${ }^{14,29,25,30}$

Previous studies in developing countries also showed high prevalence of malnutrition among the elderly as assessed by MNA. A very high prevalence of malnutrition (43.3\%) was documented among the Pakistani elderly. ${ }^{41}$ A study from Bangladesh, Kabir et al reported $26 \%$ elderly population was malnourished. ${ }^{42}$ Another study from Nepal, documented $24.8 \%$ malnutrition among dalit elderly. ${ }^{43}$ Studies from Korea and China revealed $22.3 \%$ and $19.6 \%$ prevalence rate of malnutrition which was greater than the prevalence rate of our review study. ${ }^{44,45}$ But a review study on Iranian elderly done on 17 studies and found prevalence rate was $12.2 \%$ of malnutrition by Meta-analysis which was better than the condition of Indian elderly. ${ }^{46}$

In developed courtiers, the nutritional scenario was quite better than developing countries. The prevalence rate was $1.7 \%$ among the elderly of Brazil and $2.8 \%$ among the elderly of Spain. ${ }^{47,48}$ A global review study on elderly of 38 countries reported $0.8 \%$ prevalence rate of malnutrition among the elderly of Northern Europe and $24.6 \%$ rate in South East Asian. ${ }^{49}$

The present meta-analysis on the mean score of MNA done from only 10 studies so far was found a overall mean score was 19.5 which reflected that the Indian elderly were at risk of malnutrition as assessed by MNA score (at risk of malnutrition: 17.0-23.5), indicating there is tend to be protein-calorie malnutrition that signifies implementation of nutrition supplement. The findings of this study obviously show that malnutrition may be a multi-factorial condition identified with socio-demographic, somatic, and functional status. These studies also highlighted the underlying causes of malnutrition among the Indian elderly. Foremost determinants of malnutrition are poor diet which is brought about by a lot of underlying factors: household food security, education, income, marital status, chronic morbidities, dental problem, gender and age of the elderly. Most of the studies indicated educational status

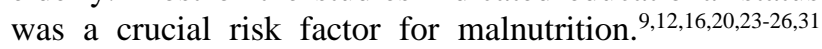
Illiteracy is extremely related to elderly malnutrition and supported by study of Baweja et al. ${ }^{50}$ Lack of education diminishes the consideration in regards to sound way of life, optimum diet which can attribute to individual nutritional status. Elderly having higher education, owing to their exposure to the outside world, are more aware of personal hygiene, curative health care than that of less educated elderly. Poor socioeconomic status or less family income was found to be independently related to malnutrition reported by many studies. ${ }^{9,10,14,16,20,25,26,31}$ This may be attributed to the undeniable reality that poor financial conditions have impact on dietary decisions of eating choices and eating patterns which ultimately affect the nutritional status of the elderly.

Another most run of the mill reason cited for poor dietary habits were meagre affordability (26\%), trouble in biting and gulping (10\%). Co-morbidities found to be significantly associated with malnutrition among the elderly as reported by earlier studies. ${ }^{14,32}$ Similar association between health problem and nutritional status was found within the study on Bangladesh. ${ }^{42}$ A pooled study showed that socially, economically and educationally weaker sections were more likely to be malnourished. Present review found risk of occurrences of malnutrition was 1.8 times higher among rural elderly than the urban elderly. A global review study on elderly of 38 countries reported that prevalence rate was 2 times higher in rural elderly than urban one (R: $9.9 \%$; U: $5.71 \%) .{ }^{49}$

In India, consistent with census 2011, there have been 104 million elderly with $71 \%$ resided in rural area and $29 \%$ resided in urban area. ${ }^{3}$ Our present review estimated that the malnourished elderly $(17.93 \%)$ in India to be $1,86,47,200$ out of total elderly population, among them $1,32,39,512$ malnourished elderly resided in rural area, whereas, 54,07,688 elderly resided in urban area. It is expected to increase $17.7 \%$ (similar to population growth from 2001-2011, while elderly population growth was $35.5 \%$ in the same period), i.e. 22 million elderly malnourished population live in India by 2021, due to elderly population growth and morbidity, poverty and joblessness by COVID-19 pandemic.

In India, majority of the rural populace comprises of tribal population. Moreover, present universal education program, there is a craving to create mass training in regards to health and elderly nutritional status within the rural regions, particularly among the educationally lagging poor socioeconomic groups. During this endeavour, participation is fundamental among the government, non- 
governmental organizations, medical personnel and also the local people. Be that as it may, significant execution of the services requires adequate manpower, infrastructure development, regular supply of quality food items, and support. Food supplement must be adopted for elderly with severe acute malnutrition, those with poor appetite or intense clinical difficulties. Then again, rapid growth of elderly population has an indirect effect on malnutrition. Accordingly, financial improvement of the nation with contribution of the considerable number of stakeholders concerned could lead to decrease of malnutrition.

In Indian sub-continent, tribal population constitutes $8.6 \%$ of the total population..$^{51}$ In accordance with the recent report entitled "nourishing India's tribal children", India's tribal communities still remain the foremost nutritionally underprivileged social groups within the country. ${ }^{52}$ They traditionally lead assorted way of life and their lifestyle is indigenous. They are more inclined to undernutrition which is perceived as a common pathological state mainly due to underutilization of existing government facilities, which has serious long run ramifications for the elderly and antagonistically impacts the event of the nation. Tribal elderly constitute $6.9 \%$ of the whole tribal population and $7.7 \%$ workforce of India. $^{3}$ It is undeniable that their backwardness is impacted by an interlacing things beginning from destitution and hunger due to loss of the forest land and livelihood, poor re-habitation measures, poor access of quality of essential food and nutrition services during critical periods of life, geographical remoteness, weak governance and inadequate accountability mechanisms. So, there is need more study to understand to actual malnutrition as assessed by MNA among tribal elderly in India.

The results of this review are useful for policy makers and programmers to formulate various developmental and health services programs. Since malnutrition is commonly thought to be modifiable, it is important to create and implement adequate interventions to forestall, diagnose, and treat malnutrition. High protein and high energy (HPHE) and diary supplementation was considered as a good intervention strategy to boost functional characteristics and reduced malnutrition of the elderly. ${ }^{53,54}$

\section{CONCLUSION}

In conclusion, the findings of this review reflect the importance of nutritional status among the elderly and proper policy making in this area. Given the expansion of elderly malnutrition in future, there is felt need a special nutrition intervention programme for the rural elderly population of India. Therefore, a dedicated geriatric friendly nutrition rehabilitation center (GFNRC) may be setup at every community development block of India.

\section{ACKNOWLEDGEMENTS}

Authors are gratefully acknowledged to the authority of Sidho Kanho Birsha University for their support and encouragement during the study. Authors are also gratefully acknowledged to all the staff of the BCW and TD Department, Government of West Bengal.

Funding: No funding sources

Conflict of interest: None declared

Ethical approval: Not required

\section{REFERENCES}

1. Cabera M, Malanowski N. Information and Communication Technologies for Active Ageing: Opportunities for Active Ageing. Netherlands: IOS Press. 2009.

2. Department of Economic and Social Affairs (DESA), Population Division. United Nations World Population Ageing. DESA/P/WP/212. 2009.

3. Census of India. Office of the Registrar General and Census Operation, Ministry of Home Affairs, Government of India, New Delhi, India. 2011.

4. MOHFW. National Program for Health Care of the Elderly (NPHCE): Operational Guidelines 2011. Ministry of health and family welfare, New Delhi: Director General of Health Services, MOHFW, Government of India. 2011.

5. MSPI. Situation Analysis of the Elderly in India. Central Statistics Office, New Delhi: Central Statistics Office, Ministry of Statistics and Programme Implementation, Government of India. 2011.

6. de Haan G, Nijhof W, Van Zant G. Mouse strain dependent changes in frequency and proliferation of hematopoietic stem cells during aging: correlation between lifespan and cycling activity. Blood. 1997;89:1543-50.

7. Fraga MF, Esteller M. DNA methylation: A profile of methods and applications. Biotechniques. 2002;33:632-9.

8. Nestle Nutrition Institute. Mini Nutritional Assessment. Nestle Nutrition Institute. Available at: http://www.mna-elderly.com/. Accessed on: 17 July 2019.

9. Abraham J, Navaneetha N, Johns F, Aiyappan R, Mili M, Shibu P, Mathew E. Nutritional status of older adults in a community in Pathanamthitta district of Kerala. Int J Res Med Sci. 2018;6:210-5.

10. Agarwalla R, Saikia AM, Baruah R. Assessment of the nutritional status of the elderly and its correlates. J Fam Community Med. 2015;22:39-43.

11. Banerjee R, Chahande J, Banerjee S, Radke U. Evaluation of relationship between nutritional status and oral health related quality of life in complete denture wearers. Indian J Dent Res. 2018;29:562-7.

12. Biswas P, Chakraborty A, Samsuzzaman M, Mondal R, Bhattacharya T, Das DK. Nutritional status and family dietary pattern among slum dwelling geriatric population in an area of Burdwan Municipality, West Bengal. IOSR J Dent Med Sci. 2018;17:59-64.

13. Gandhi SJ, Choudary MK, Kumar R, Bhatnagar D. Nutritional status of the geriatric population in the 
field practice area of a medical college in Rajasthan. Int J Community Med Public Health. 2018;5:220-4.

14. Ghosh A, Dasgupta A, Paul B, Sembiah S, Biswas B, Mallik N. Screening for malnutrition among the elderly with MNA scale: a clinic based study in a rural area of West Bengal. Int J Contemp Med Res. 2017;4:1978-82.

15. Jose S, Kumari K. Validity assessment of MNA among an elderly population in Kerala, South India. Int J Adv Res. 2014;2(2):214-21.

16. Joymati O, Ningombam M, Rajkumari B, Gangmei A. Assessment of nutritional status among elderly population in a rural area in Manipur: communitybased cross-sectional study. Int J Community Med Public Health. 2018;5:3125-9.

17. Kavya C, Santosh A. Geriatric health: assessment of nutritional status and functional ability of elderly living in rural area of Bangalore, Karnataka, India. Int J Community Med Public Health. 2016;3:3460-4.

18. Kansal D, Baliga SS, Kruthika K, Mallapur MD. Nutritional assessment among elderly population of rural Belagavi: a cross-sectional study. Int J Med Sci Public Health. 2016;5:1496-9.

19. Khandhedia S, Unadkat S, Parmar D. A Study on the Assessment of Nutritional Status among Geriatric Population in Jamnagar City. Healthline J. 2015;6:44-8.

20. Konda S, Ravi Kumar BP, Giri PA. Prevalence of malnutrition and its determinants in an elderly people in South India. Int $\mathbf{J}$ Med Sci Public Health. 2018;5:3570-6.

21. Krishnamoorthy Y, Vijayageetha M, Kumar SG,Rajaa S, Rehman T. Prevalence of malnutrition and its associated factors among elderly population in rural Puducherry using mini-nutritional assessment questionnaire. J Family Med Prim Care. 2018;7:1429-33.

22. Kritika D, Semwal J, Vyas S, Juyal R, Sati HC. Nutritional status and associated comorbidities among the elderly in Doiwala Block, Dehradun. Indian J Community Health. 2014;26(2):197-203.

23. Kshetrimayum N, Reddy CVK, Siddhana S, Manjunath M, Rudraswamy S, Sulavai S. Oral health-related quality of life and nutritional status of institutionalized elderly population aged 60 years and above in Mysore City, India. Gerodontology. 2013;30:119-25.

24. Kutikuppala A, Mathur N, Prakash TLG. Nutritional status of elderly people using mini nutritional assessment tool in an urban slum of Hyderabad. Int $\mathrm{J}$ Med Sci Public Health. 2018;7(11):885-8.

25. Lahiri S, Biswas A, Santra S, Lahiri SK. Assessment of nutritional status among elderly population in the rural areas of West Bengal, India. Int $\mathbf{J}$ Med Sci Public Health. 2015;4(4):569-72.

26. Majumder M, Saha I, Chaudhuri D. Assessment of nutritional risk in community dwelling older adults (65 to 75 years) in Kolkata, India. J Nutr Gerontol Geriatr. 2014;33:126-34.
27. Mathew AC, Das D, Sampath S, Vijayakumar M, Ramakrishnan N, Ravishankar SL. Prevalence and correlated of malnutrition among elderly in an urban area in Coimbatore. Ind $\mathbf{J}$ Public Health. 2016;6(2):112-7.

28. Pai MK. Comparative study of nutritional status of elderly population living in the home for aged vs. those living in the community. Biomed Res. 2011;22:120-6.

29. Patel P, Shivakumar KM, Patil S, Suresh KV, Kadashetti V. Association of oral health-related quality of life and nutritional status among elderly population of Satara district, Western Maharashtra, India. J Indian Assoc Public Health Dent. 2015;13:269-73.

30. Patil DJ, Shindhe MM. Nutritional status assessment of elderly using MNA tool in rural Belagavi: a cross sectional study. Int J Community Med Public Health. 2018;5:4799-803.

31. Ramya MS, Ranganath TS, Jadhav J, Swetha NB. To assess the nutritional status among elderly and factors influencing it, in an urban area, Bengaluru - a cross sectional study. Int J Community Med Public Health. 2017;4:1727-32.

32. Shanbhag D, Balasubramanya B, Austin J, D’Souza R, Sachdeva R, John J, Goud R. Nutritional status and functional ability of the elderly in rural area of South India: a cross sectional study. Int J Med Res Prof. 2017;3(1):138-42.

33. Saha S, Basu A, Ghosh S, Saha AK, Banerjee U. Assessment of nutritional risk and its associated factors among elderly women of old age homes of south suburban Kolkata, West Bengal, India. J Clin Diagnos Res. 2014;8(2):118-20.

34. Santosh A, Srinivas N, Varadaraja Rao BA. Geriatric nutrition: elderly at risk of malnutrition in old age homes. Natl J Community Med. 2017;8(8):447-50.

35. Shivraj M, Singh VB, Meena BL, Singh K, Neelam M, Sharma D, Beniwal S. Study of nutritional status in elderly in Indian population. Int J Curr Res. 2014;6:10253-7.

36. Sinha U, Mukhopadhyay B. Relationship of nutrition and handgrip strength of elderly of Kolkata. J Indian Acad Geriatr. 2013;9(3):102-8.

37. Vedantam A, Subramanian V, Rao NV, John KR. Malnutrition in free-living elderly in rural south India: prevalence and risk factors. Public Health Nutr. 2010;13(9):1328-32.

38. Yadav N, Ravindra R, Sharma S, Singh A, Mishra M, Dubey J, et al. Dietary habits and nutritional status of elderly living in urban areas of Allahabad district. Indian J Prev Social Med. 2012;43(1):80-6.

39. World Health Organization. The World Health Report 2008: Primary Health Care (Now more than ever); Available at: http://www.who.int/whr/2008/ en/. Accessed on: 12 July 2019.

40. Gnanaselvam NA, Kumar SPV, Abraham VJ. Assessment of nutritional status of people with disabilities in rural Tamil Nadu using mini nutritional 
assessment scale. Curr Nutr Food Sci. 2018;14(4):341-9.

41. Momin A, KA Ronis. Nutritional status of Pakistan's elderly population: a comparative review with low to middle income countries. Pakistan J Public Health. 2015;5(2):22-5.

42. Kabir ZN, Ferdous T, Wahlin A, Streatfield K, Cederholm T. The multidimensional background of malnutrition among rural older individuals in Bangladesh - A challenge for the Millennium Development Goal. Public Health Nutr. 2009; 12:2270-8.

43. Tamang M, Yadav UN, Hosseinzadeh H, Kafe B, Paudel G, Khatiwada S, Sekaran VC. Nutritional assessment and factors associated with malnutrition among the elderly population of Nepal: a crosssectional study. BMC Res Notes. 2019;12:246.

44. Chung SH, Sohn CM. Nutritional status of hospitalized geriatric patients using the Mini Nutritional Assessment. Korean J Community Nutr. 2005; 10:645-53.

45. Lei Z, Qingyi D, Feng G, Chen W, Hock RS, Changli W. Clinical study of mini-nutritional assessment for older Chinese inpatients. J Nutr Health Aging. 2009; 13(10):871-5.

46. Gorji, HA, Alikhani M, Mohseni M, Moradi-Joo M, Ziaiifar H, Moosavi A. The prevalence of malnutrition in Iranian elderly: a review article. Iran J Public Health. 2017;46(12):1603-10.

47. Damião R, Santos, ÁS, Matijasevich A, Menezes PR. Factors associated with risk of malnutrition in the elderly in south-eastern Brazil. Rev Bras Epidemiol. 2017;20:598-610.

48. Serrano-Urrea R, Garcia-Meseguer MJ. Malnutrition in an elderly population without cognitive impairment living in nursing homes in Spain: study of prevalence using the mini nutritional assessment test. Gerontology. 2013;59:490-8.

49. Crichton M, Craven D, Mackay H, Marx W, de van der Schueren M, Marshall S. A systematic review, meta-analysis and meta-regression of the prevalence of protein-energy malnutrition: associations with geographical region and sex. Age Ageing. 2019;48:38-48.

50. Baweja S, Agarwal H, Mathur A, Haldiya K R and Mathur A. Assessment of nutritional status and related risk factors in community dwelling elderly in Western Rajasthan. J Indian Acad Geriatr. 2008;1:513.

51. Bisai S, Saha KB, Sharma RK, Muniyandi M, Singh N. An overview of tribal population in India. Tribal Health Bull. 2014;20(Special issue):1-126.

52. UNICEF. Improving Child Nutrition: The Achievable Imperative for Global Progress. 2014. Available at: https://www.unicef.org/ publications/index_68661.html. Accessed on: 17 July 2019.

53. Iuliano $\mathrm{S}$, Poon $\mathrm{S}$, Wang $\mathrm{X}$, Bui $\mathrm{M}$ and Seeman $\mathrm{E}$. Dairy food supplementation may reduce malnutrition risk in institutionalised elderly. British $\mathrm{J}$ Nutr. 2017;117:142-7.

54. Sossen L, Bonham M, Porter J. Does a high-protein high-energy diet reduce unintentional weight loss in residential aged care residents? J Nutr Geroltol Geriatr. 2020;39:56-68.

Cite this article as: Bisai S, Dey U. Malnutrition assessed by mini nutritional assessment tool among Indian elderly: a systematic review and meta-analysis. Int J Community Med Public Health 2020;7:4672-80. 